\title{
The future of preventive dentistry and the fourth industrial revolution
}

\author{
Choong-Ho Choi
}

President of The Korean Academy of Preventive Dentistry and Oral Health

The General Conference of Korean Academy of Preventive Dentistry and Oral Health was held in October of this year with the theme of "Promising Vision and Strategy for Preventive Dentistry." It provided an opportunity to reflect on the history of preventive dentistry and dream about the future based on the present. Advances associated with the Fourth Industrial Revolution can be considered one of the subjects that has drawn much recent interest and discussion with respect to the future of preventive dentistry.

The Fourth Industrial Revolution refers to creating a hyper-connected society through the convergence of core technologies. It entails establishing a mutual communication system between production equipment and products through Internet of Things and optimizing the entire production process. It also entails creating a world of networks in which large quantities of information could be shared through convergence of technologies that blur the boundaries between different fields such as physics, biology, and digital technology, and through human-to-things and machine-to-machine connections. Core technologies such as 3D printing, artificial intelligence, big data, and virtual reality, which are the future technologies that represent the Fourth Industrial Revolution, are having a major impact on dentistry and will have even greater impact moving forward. Digital dentistry, which has undergone rapid advances in recent years, can be an example, in which current developments are for treatment purposes such as surgery and restoration. However, in the future, I believe that core technologies of the Fourth Industrial Revolution will be useful for the development of preventive dentistry, including big data-based research on oral health using large quantities of data and oral health education using virtual reality.

Therefore, I hope that researchers studying oral health will take an even greater interest in the Fourth Industrial Revolution and achieve more effective, efficient, and groundbreaking advancements by integrating the contents of current research with new technologies. Moreover, I am also hopeful that introduction and sharing of such new efforts and advancements through academic journals could provide the opportunities to gain synergistic effects.

December 2019 


\section{예방치의학의 미래와 4차 산업혁명}

최충호

대한예방치과·구강보건학회장

올해 10 월에 개최된 대한예방치과·구강보건학회 종합학술대회는 '예방치의학 분야의 새로운 비전과 전략'이라는 주제로 예방치의학의 과거 를 돌아보고 현재를 기반으로 미래를 꿈꾸어 보는 기회를 제공하였다. 미래의 예방치의학과 관련하여 최근에 많은 관심과 논의의 대상이 되고 있 는 것 가운데 하나로 4차 산업혁명과 관련된 발전을 생각해 볼 수 있다.

4차 산업혁명이란 핵심기술이 융합되어 초연결사회를 만들어 가는 것으로, 사물인터넷을 통해 생산 기기와 생산품 간 상호소통체계를 구축 하고 전체 생산과정의 최적화를 구축하고 물리학, 생물학, 디지털 등 영역 간 경계가 완전히 허물어진 기술융합과 사람과 사물, 기계와 기계의 연 결로 대량의 정보 공유가 가능한 네트워크세상을 만들어가는 것이다. 이러한 4차 산업혁명의 대표 미래 기술인 3D 프린팅을 포함한 인공지능, 빅 데이터, 가상현실과 같은 핵심기술들은 치과계에 큰 영향을 미치고 있고 앞으로 더 많은 영향을 미치게 될 것이다. 최근에 급속도로 발전하고 있 는 디지털 덴티스트리(Digital Dentistry)가 하나의 예시가 될 수 있는데 현재는 수술과 수복 등 치료를 목적으로 개발이 이루어지고 있으나 앞으 로 대용량 데이터를 활용한 빅데이터 연구를 통한 구강보건관련 연구, 가상현실을 이용한 구강보건교육 등 예방치의학의 발전을 위해 4차산업혁 명의 핵심기술들이 유용하게 활용될 것으로 생각한다.

따라서 구강보건을 연구하는 연구자들이 이러한 4차산업혁명에 보다 더 깊은 관심을 가지고 현재 연구하고 있는 내용들을 새로운 기술들과 융합시켜 나감으로써 보다 더 효과적이고 효율적이며 획기적인 발전을 이룰 수 있기를 바라고, 이러한 새로운 시도와 발전이 학회지를 통해 소개 되고 공유되어 시너지 효과를 얻을 수 있는 기회가 될 수 있기를 기대한다.

2019. 12. 